\title{
Ticaret Savaşları ve Dünya Ekonomisine Etkileri
}

\section{Nuran ERTÜRK}

\section{Trade Wars And Their Effects On World Economy}

\section{ARTICLE INFO}

Article History:

Date Submitted: 17.08 .2016

Date Accepted: 03.02.2017

JEL Classification:

F13

F15

F41

Keywords:

Global Crisis

Currency Wars

Trade Wars

Protectionism Policies

\section{ABSTRACT}

The crisis first emerged in the housing industry between 2007 and 2008 in the United States, has turned into a global crisis by effecting whole financial markets. This crisis caused serious damage to all real markets due to globalization policies implemented worldwide after 1980 and globalization policies started to be questioned. As a result of reduced confidence in globalization policies, developed and developing countries have started a process of returning to protectionism as a solution to the crisis. Meanwhile the currency wars that started in this process and it's transformation into trade wars causes new forces to emerge in the world economy, such protectionism policies are not actually an issue, but rather caused new crises. In this study it was argued that effects of protectionism policies implemented after the global crisis and trade wars caused by playing with currencies on world economy. 


\section{Özet}

ABD’de 2007-2008 yılları arasında ilk olarak konut alanında ortaya çıkan kriz, ardından tüm finansal piyasaları etkisine alarak küresel krize dönüşmüştür. Bu kriz 1980 sonrası tüm dünyada uygulamaya konan küreselleşme politikaları nedeniyle tüm reel piyasalar üstünde ciddi hasarlara neden olmuş ve küreselleşme politikaları sorgulanmaya başlanmıştır. Küreselleşme politikalarına olan güvenin azalması sonucu, gelişmiş ve gelişmekte olan ülkeler krizden çıkış için çözüm olarak korumacılık politikalarına doğru geri dönüş süreci başlatmıştır. $\mathrm{Bu}$ süreç doğrultusunda başlayan kur savaşları ve onun ticaret savaşlarına dönüşümü, dünya ekonomisinde yeni güçlerin ortaya çıkmasına sebep olurken, bu tür korumacılık politikaları aslında bir çıkış olmamakta, aksine yeni krizlere sebep olmaktadır. $\mathrm{Bu}$ çalışmada Küresel Kriz sonrasında uygulamaya konan korumacılık politikaları ve kurlar ile oynanmaların yol açtığı ticaret savaşlarının dünya ekonomisinde ne tür etkilere yol açtı ğı tartışılmıştır.

Anahtar Kelimeler: Küresel Kriz, Kur Savaşları, Ticaret Savaşları, Korumacılık Politikalarl

Giriş

Bilinen insanlık tarihine bakıldığında insanların topluluklar halinde yaşamaya başladıkları ve tarihsel koşulların ilerleyiş̧ine bağlı olarak da özel mülkiyetin ortaya çıktığı görülmektedir. $\mathrm{Bu}$ çıkışın yarattığı sonuçlardan birisi, dünya tarihinin pek çok savaşa ve yıkıma sahne olmasıdır. Savaş denildiğinde ilk akla gelen ülkeler veya siyasi gruplar arasında gerçekleşen silahlı mücadelelerdir. $\mathrm{Bu}$ anlama bakarak tarihsel gelişim sürecini gözlemlediğimiz de görüyoruz ki savaşların büyük çoğunluğu fiziki savaşlar olarak gerçekleşmiştir, ancak büyük fiziki savaşlar, teknolojik ve ekonomik gelişimlerle birlikte dönüşüme uğramaya kılıçlı, silahlı savaşlar yerini daha çok ekonomik ve kültürel savaşlara bırakmaya başladığını söylemek mümkün hale gelmiştir. Oluşan bu yeni savaş biçimi daha çok ekonomik enstrümanlar üzerinden yapılarak kendine tarih sahnesinde yer edinmeye başlamıştır, ekonomik savaş biçiminin en önemlisi ülkelerin kendi ekonomik çıkarları doğrultusunda uyguladıkları korumacı gösterilebilir. Ülkelerin özellikle kriz dönemlerinde uygulamaya başladıkları korumacı politikaların neden olduğu kur savaşları ve beraberinde 
getirdiği ticaret savaşları çağımızın en önemli ekonomik sorunu olacağını söylemek yanlış olmayacaktır. Tarih boyunca bütün savaşlar büyük yıkımlara yol açmış ve bu yıkımlardan en çok az gelişmiş ülkeler ve yoksullar etkilenmiştir, fiziki savaşlar da olduğu gibi ekonomik savaşlar sonucunda yine en çok etkilenen kesimin az gelişmiş ülkeler ve yoksullar olduğunu söylemek yanlış olmayacaktır. Bu çalışmanın amacı Ticaret Savaşlarının Dünya Ekonomisine Etkileri, küresel kriz sonrası yeniden gündeme gelen korumacılık önlemleri ve korumacılık uygulamalarının en önemlisinden olan kur savaşlarını ve kur savaşlarının yol açtığı ticaret savaşlarının dünya ekonomisi üzerinde ki etkilerinin neler olduğunu anlatmaktır.

\section{Küresel Kriz Sonrasında Uygulanan Korumacı Önlemler}

2007 y1lında ABD'de konut krizi olarak ortaya çıkan finans kaynaklı kriz 2008'den itibaren dünyaya yayılmaya başlamıştır. Bu kriz 1929 Dünya Ekonomik Buhranın ardından yaşanan en büyük kriz olarak tarihe geçmiştir. ABD başta olmak üzere gelişmiş ülkeleri büyük oranda etkileyen bu finansal kriz kısa bir süre içerisinde gelişmekte olan ülkeleri de etkileyerek dünya genelinde ciddi bir sorunlara neden olmuştur. Bu krizin dünya ekonomisi üzerindeki yıkıcı etkisi; finans koşullarındaki bozulma ve toplam talep gerilemesi ile birlikte küresel ticaretin yavaşlaması şeklinde olmuştur. Kriz etkisini tüm dünya da hızlı bir şekilde yayılarak göstermiştir bunun en önemli nedenlerinden biri ise 80'li yıllardan günümüze kadar hızla yayılarak devam eden özellikle 2000'li yıllarda en üst aşamaya gelen küreselleşme sürecidir. Küreselleşmenin getirdiği dünya ekonomilerinin ve finans sistemlerinin birbirine entegre olma süreci ülkelerin birbirlerine bağlılıklarını artırması ekonomilerin bu krizden daha hızlı ve daha çok etkilenmesine neden olmaktadır.

Küresel krizin patlak vermesinin arından 2008 yılının son çeyreğinde ülkelerin açıklanan büyüme rakamlarına bakıldığında $\mathrm{BRIC}^{1}$ ülkeleri dışında kalan tüm büyük ülkeler ve Türkiye’nin büyüme oranlarında küçülmeler görülmektedir.

Kuşkusuz küresel alanda ki ekonomik faaliyetler yavaşladıkça finansal yapının varlığını sürdürmesi zorlaşmış ve dünya ticaret akımlarında düşüş gözlenmeye başlamış, nitekim küresel krizin derinleşmesi ile birlikte küresel boyutta yaşanan durgunluk, etkisini uluslararası ticaret alanında da göstermiş ve birçok sanayileşmiş ülkenin dış ticaret hacmi, bir

\footnotetext{
${ }^{1}$ Brezilya, Rusya, Hindistan ve Çin
} 
önceki yıla göre \%20'lerin üzerinde daralmıştır. 2008 yılında başlayan bu düşüş, bütün büyük ekonomileri derinden etkilemeye başlamıştır. $\mathrm{Bu}$ bağlamda gerek söz konusu endişeler gerekse ekonomik belirsizlik ortamı küresel krize çözüm arayışları içerisinde pek çok ülkede reel sektöre destek sağlayarak istihdam yaratan büyük firmaların ayakta kalmasına yönelik önlem paketleri uygulamaya konulmuştur. Kriz sonrası ekonomik göstergelerin daha da kötüleşmesi ve bunun etkilerinin ekonomik aktörler tarafından iyice hissedilmeye başlanmasıyla, uluslararası anlaşmaları ve serbest piyasa ekonomisinin temel argümanın zedeleyen korumacı ve içe kapanma gibi önlemlerin uzun vadede pek çok ülke için bir kurtuluş reçetesi olacağı inancı yaygınlık kazanmıştır. Bu yaygın inançla birlikte korumacı uygulamalar gündeme gelmeye başlamıştır. Yani küresel finansal ve ekonomik krizin derinleşmesiyle birlikte krizden büyük zarar gören sektörlerde ve işsizlik oranının yükselmesi ile işçi kesiminde serbest ticaret karşıtı ve korumacılık taraftarı baskılar doğal olarak güç kazanmıştır (TÜRMOB, 2009'dan aktaran: Durusoy, 2013:511).

Korumacılık, genel anlamda yabancı kökenli malların iç piyasaya girişini sınırlamaya veya iç piyasada yerli malların yabancı kökenli mallara tercih edilmesini sağlamaya yönelik düzenlemeler olarak tanımlanmaktadır. Bu kapsamda; ithalat yasakları, miktar sınırlamaları, gümrük vergi harçlarının koyulması, döviz tahsis sınırlamaları gibi çeşitli yöntemler uygulanmaya konulmuştur. Başka bir söylemle korumacılık; bir ülkenin yerli üreticilerini her türlü yıkıcı nitelikteki dış rekabet karşısında korunmasını savunan görüşlere dayanan dış ticaret politikası olarak görülmektedir ${ }^{2}$. Bu politika araçlarının en önemlilerinde birkaçını şöyle sıralanabilir.

- Gümrük vergileri

- Miktar kisitlamaları

- İthalat kotaları

- Sübvansiyonlar

- Dış ticarette devletleştirme

${ }^{2}$ P. Övgü, H. Uzunoğlu, Dünyada Kur Savaşları Alarmı, AR\&GE Bülten, 2013 Haziran http://www.izto.org.tr/portals/0/argebulten/ovgu_hande_kursavaslari.pdf 
- Gönüllü ihracat kısıtlamaları

- Anti-Damping vergi uygulamaları

Dünya Ticaret Alarmı (GTA) adlı girişimin hazırladığı raporda 2008 yılından beri küçük ve büyük çapl1 192 ayrı korumacılık adımı atıldığı ve bu konuda en etkili ülkenin Çin olduğu görülmektedir. Bu uygulamalar göstermektedir ki Dünya Ticaret Örgütü ' 'çok taraflı ticaret rejimine yönelik" çalışmalarından vazgeçtiğini söylemek mümkündür. Günümüzde uluslararası ticaretin çoklu ticaret sistemine bağlı bir şekilde yürüdügünü düşündügüumüzde Bhagwati (2009), serbest ticarete müdahaleye izin verilmemesini, sınır ötesi ticarete engeller konmasını ve yerli üreticinin dış rekabete karşı korunmasını öngören, korumacılık anlayışının, korumacılığın çok güçlü bir “yanıt isteyen tehlikeli bir virüs” olduğunu söyleyen düşüncesine katılmamak mümkün değildir; G20 liderlerinin başında gelen Obama'nın çok ciddi iki korumacı meydan okumayla yüzleştiğini; bu meydan okumalardan ilkinin "Amerikan malını satın alın" şeklindeki talep uyarıcı paketi, diğerinin ise "Çin'in döviz hilesi” olduğunu belirtmektedir.(Kalayc1, 2008:80)

Tablo 1'de, dünyanın en büyük ülkelerinden oluşan G8, G20 ve Euro Bölgesi ülkeleri tarafından alınmış koruma kararlarının bir listesi görülmektedir. Krizin yoğun yaşandığı Kasım 2008 ile Aralık 2009 arasında, G8 grubu 186 ve G20 grubu 390 tane korumacı önlem alırken, Euro bölgesi sadece 23 adet önlem almakla yetinmiştir. Öyle anlaşıllyor ki, Avrupalılar ticareti serbestleştirme yönünde dikkatli (sadece 4 tane) davranmışlardır. Dünyanın bu en büyük ekonomi grupları tarafından alınan korumacı kararlardan dolayı etkilenen sektör ve şirket sayısı da oldukça fazladır (Kalaycı, 2011:75). 
Tablo 1: Küresel Kriz Sürecinde- Dış Ticareti Etkileyen- Alınmış Önlemler

\begin{tabular}{|l|l|l|l|l|l|}
\hline $\begin{array}{l}\text { Kasım 2008- } \\
\text { Aralık 2009 }\end{array}$ & $\begin{array}{l}\text { Alınan önlem } \\
\text { sayısı (1)+ } \\
(2)\end{array}$ & $\begin{array}{l}\text { Ticari } \\
\text { serbestleşme } \\
\text { ya da sıfır- } \\
\text { nötr } \\
\text { korumacı } \\
\text { önlemler (1) }\end{array}$ & $\begin{array}{l}\text { Korumac1 } \\
\text { önlemler } \\
\text { (henüz } \\
\text { uygulanan ya } \\
\text { da ilan edilen } \\
(2)\end{array}$ & $\begin{array}{l}\text { Uygulanan } \\
\text { korumac1 } \\
\text { önlemlerin } \\
\text { etkilediği } \\
\text { sektör sayıs1 } \\
(3)\end{array}$ & $\begin{array}{l}\text { Uygulanan } \\
\text { korumac1 } \\
\text { önlemlerin } \\
\text { etkilediği } \\
\text { ticaret ortağ1 } \\
\text { sayıs1 (4) }\end{array}$ \\
\hline G8 & 207 & 21 & 186 & 51 & 179 \\
\hline G20 & 446 & 56 & 390 & 58 & 196 \\
\hline Euro Bölgesi & 27 & 4 & 23 & 14 & 118 \\
\hline
\end{tabular}

Kaynak: Global Trade Alert'den aktaran Bussiere vd., (2010:29)

Tablo 2'de ise, dünyanın en büyük yirmi ekonomisi olan G20 ülkeleri tarafından kriz konjonktüründe uygulamaya konan ve 'zarar verici' özellikleri olan korumacı önlemler tür ve sayıları ile listelenmiştir. Bussière, vd. (2010) tarafından, toplam sayısı 234 olarak saptanan korumacı önlemler içinde en fazla uygulanan ilk üç tür "savunma" (73 tane), "devlet yardımı" (58) ve "tarifeler" (36) iken, hiç uygulanmayanlar "rekabetçi devalüasyon", "ithalat desteği" ve "fikri mülkiyet korumacılığı" gibi önlemler olmuştur (Kalaycı, 2011:75).

Tablo 2: G20 Ülkelerinin Uyguladığı 'Zarar Verici’ Önlem Türü ve Sayısı

\begin{tabular}{|l|c|}
\hline Önlem Türü & Önlem Sayısı \\
\hline Devlet yardımı/Kurtarma planı & 58 \\
\hline Rekabetçi devalüasyon & 0 \\
\hline Tüketim desteği & 2 \\
\hline İhracat desteği & 11 \\
\hline İhracat vergisi ya da kısıtlanması & 5 \\
\hline İthalat yasağ1 & 4 \\
\hline İthalat desteği & 0 \\
\hline Fikri mülkiyet korumacılığ & 0 \\
\hline Yatırım önlemi & 4 \\
\hline Yerel memnuniyet koşulu & 3 \\
\hline
\end{tabular}

\footnotetext{
${ }^{3}$ Tablolar Kalaycı'nın ' Küresel Finans Krizine Karşı Korumacılık’' Makalesinden alınmıştır.
} 


\begin{tabular}{|l|c|}
\hline Göç önlemi & 5 \\
\hline Tarife dışı engeller & 12 \\
\hline Diğer hizmet sektörü önlemi & 3 \\
\hline Kamu mal/sermaye tedariki & 8 \\
\hline Kota & 4 \\
\hline İnsan ve bitki sağlığı önlemi & 6 \\
\hline Devlet ticaret girişimi & 3 \\
\hline Devlet kontrollü şirket & 4 \\
\hline Yarı ulusal hükümet önlemi & 0 \\
\hline Tarife önlemi & 36 \\
\hline Ticaret teknik engeller & 2 \\
\hline Güvenlik nedeniyle savunma & 73 \\
\hline Ticaret finansmanı & 4 \\
\hline Toplam & 234 \\
\hline
\end{tabular}

Kaynak: Bussière, Matthieu, Emilia Pérez-Barreiro, Roland Straub ve Daria Taglioni (2010), "Protectionsist Responses to the Crises Global Trends and Implications", makalesinden alıntılanmıştır.

Krizden çıkmak için uygulanan korumacılık uygulamalarının krizi daha da derinden etkileyeceği endişesi nedeniyle ülkeler korumacılığa karşı çeşitli önlemler almışlardır. Tablo 3’te, korumacılığı, kriz konjonktüründe dış ticaret politikalarının odağı haline getiren ülkelerde alınan ayrımcı önlemlerin niceliği ve niteliği hakkında bazı fikirler vermektedir. Evenett'in sunduğu verilere göre, örneğin, AB27 2009 yılında (166 tane) en fazla ayrımc1 önlem düzenleyen, Vietnam en fazla (926) tarife sınırı getiren, Cezayir ayrımcı önlemlerle en fazla (67) sektörel etki yapan ve Arjantin ise (174) ayrımcı önlemle en fazla ticaret ortaklarını etkileyen ülke sayılmaktadır. Özellikle G20 ve OECD-dışı ülkeler finansal krizin aşılması sürecinde uyguladıkları korumacı politikalarla, dünyanın en az gelişmiş ülkelerine (LDC) 'zarar' vermişlerdir. Bu durumla ilgili Tablo 5'e göre, 2008'de LDC kesimi, korumacilık yoluyla en çok darbeyi (108 zararlı önlemle) OECD dışı ülkelerden yemiştir. 
Tablo 3: Korumacı Politikalara Karşı Alınan Önlemler Belirli Gelişen Piyasalar ve Avrupa Ülkeleri İçin Bir Karşılaştırma

\begin{tabular}{|c|c|c|c|c|}
\hline Sira & \multicolumn{4}{|c|}{ Seçilmiş Ülkelere (korumacı önlemler sayısı) } \\
\hline & $\begin{array}{l}\text { Düzenlenen } \\
\text { ayrımcı } \\
\text { önlemlerin sayısı }\end{array}$ & $\begin{array}{l}\text { Ayrımcı önlemlerin } \\
\text { etkilediği (ürün } \\
\text { kategorisinde) tarife } \\
\text { sinırları sayısı }\end{array}$ & $\begin{array}{l}\text { Ayrımcı } \\
\text { önlemlerin } \\
\text { etkilediği } \\
\text { sektör sayısı }\end{array}$ & $\begin{array}{l}\text { Ayrımcı } \\
\text { önlemlerin } \\
\text { etkilediği ticaret } \\
\text { ortakları sayısı }\end{array}$ \\
\hline 1. & AB27 (166) & Vietnam (926) & Cezayir (67) & Arjantin (174) \\
\hline 2. & Rusya (85) & Venezüella (785) & $\mathrm{AB} 27(56)$ & $\mathrm{AB} 27(68)$ \\
\hline 3. & Arjantin (52) & Kazakistan (723) & Nijerya (45) & Çin (160) \\
\hline 4. & Hindistan (47) & Nijerya (599) & \multirow{2}{*}{$\begin{array}{l}\text { Venezüella (38) } \\
\text { Vietnam (38) }\end{array}$} & Endonezya (151) \\
\hline 5. & Almanya (35) & Cezayir (476) & & Vietnam (48) \\
\hline \multirow[t]{2}{*}{6.} & \multirow[b]{2}{*}{ Brezilya (32) } & \multirow[b]{2}{*}{ AB27 (467) } & \multirow{4}{*}{$\begin{array}{l}\text { Almanya (36) } \\
\text { Kazakistan (36) } \\
\text { Rusya (36) }\end{array}$} & Hindistan (145) \\
\hline & & & & \multirow[b]{2}{*}{ Rusya (143) } \\
\hline 7. & $\begin{array}{l}\text { Birleşik Krallık } \\
\text { (31) }\end{array}$ & Rusya (426) & & \\
\hline 8. & İspanya (25) & Arjantin (396) & & \multirow{3}{*}{$\begin{array}{l}\text { Finlandiya (132) } \\
\text { Almanya (132) } \\
\text { Güney Afrika } \\
(132)\end{array}$} \\
\hline 9. & \multirow{2}{*}{$\begin{array}{l}\text { Endonezya (24) } \\
\text { İtalya (24) }\end{array}$} & Hindistan (365) & Etiyopya (32) & \\
\hline 10. & & Endonezya (347) & Hindistan (32) & \\
\hline
\end{tabular}

Kaynak: Evenett, Simon J. (2010), The State of Protectionism on the Eve of the Seoul G20 Summit, Nov., http://www.voxeu.org/index.php?q=node/5753

Küresel krizin etkileri derinleştikçe korumacı politika söylemleri artmaya başlamıştır, bu öngörülen korumacı politika çağrılarına karışı dünya da önemli tepkiler de yükselmeye başlamıştır.

Küresel krizin başlamasından hemen ardından, 15 Kasım 2008 tarihinde bir araya gelen G-8 ülkelerine, büyük gelişmekte olan ülkelerin eklenmesiyle oluşturulan G-20'in liderleri korumacı önlemler almayacakları taahhüdünde bulunulmuş. Daha sonra şubat ayında bir araya gelen G-7 Maliye Bakanları da "çöküşü daha da hızlandırmaktan başka bir işe yaramayacak korumacı önlemlerden kaçınacaklarını" bildirmişlerdir. Tüm bunlara açıklamalara rağmen, Dünya Bankası Uluslararası Ticaret Bölümü, Mart 2009 başında diğer birçok ülkenin yanı sıra 17 G-20 üyesinin de diğer ülkelerin zararına olacak şekilde dış 
ticareti sınırlayıcı çeşitli önlemler aldıklarını duyurmuştur. Yayımlanan 6. Rapora göre toplam 47 önlem bulunmakta bunların arasında sanayileşmiş ülkelerin aldığı 12 önlem ilk etapta tamamen sübvansiyon ile diğer destek paketlerinden oluşmakla beraber gelişmekte olan ülkelerin aldığı 35 korumacı önlemin neredeyse yarısı gümrük vergilerini artırmak, \%9'uysa bazı ürünlerin ithalatını tamamen yasaklamak şeklinde olmuştur. (Öz, 2008: 6)

Dünya Bankası Uluslararası Ticaret Bölümü raporunda toplam 47 korumacı önlem politikalarından söz edilmektedir, küresel krizi başlatan mali sektöre verilen destekler ve 2008 'in ikinci yarısında artma eğilimi gösteren anti damping önlemleri ise bu korumac1 önlemlere dahil değildir. Anti damping uygulamalarına en çok başvuruyu, krizden en çok zarar gören gelişmekte olan ülkeler yapmış olsa da gümrük vergisi koyma hakkını en çok kazanan ülkeler $\mathrm{ABD}$ ve $\mathrm{AB}$ olmuştur.

Tüm bu korumacılık önlemlerinin yarattı̆̆ı tehlikeye bir örnekte 2008 Şubat ayında ABD'de Başkan Obama tarafından imzalanan ekonomik destek paketine Senato'daki görüşme aşamasında bazı maddeler eklemiştir ve bu maddeler dünya ticareti açısından oluşturduğu tehlike gösterilebilir. Ekonomik destek paketindeki maddelerde, bu paket çerçevesinde yapılacak demir ve çelik alımlarında sadece ABD'de üretilen demir ve çeliğin satın alınması kısıtlaması getirilmiştir. Daha sonra bu paketin bazı maddelerine gelen tepkilere rağmen paket sadece biraz yumuşatılmış ve bu Obama tarafından imzalanarak yürürlüğe girmiştir. Kanada ve AB'nin bu yasayanın bazı maddelerine karşı çıkmasına rağmen “ABD’nin imzaladığı uluslararası anlaşmalardaki yükümlülükleriyle ters düşmediği sürece” koşulu eklenerek anlaşama yürürlüğe konulmuştur.

“Amerikan Malı Kullan” adı verilen bu yasaya bir, alınan korumacılık önlemleri, diğer ülkelere karşı kullanması ile korumacılık politikalarının yaygın hale gelmesi gibi bir sonuca neden olabileceği ve ayrıca bu tür önlemleri dünya ticaretinde önemli bir paya sahip olan bir ülke tarafından alınması durumunda sonuçların daha derinden tehlike yaratması kaçınılmaz hale geleceği için, sadece Kanada ve $\mathrm{AB}$ değil, birçok tanınmış iktisatçı da tepki göstermiştir. Washington kaynaklı bir düşünce kuruluşu olan Peterson Uluslararası Ekonomi Enstitüsü yayımladığı bir politika notunda kamu alımlarında "Amerikan Malı Kullanma" zorunluluğunun ABD’nin dış ticaret yükümlülüklerini ihlal etmekten ve ABD’nin saygınlığını 
zedelemekten başka bir işe yaramayacağını bildirmiştir. Girdileri üzerine konan bir vergi işlevi göreceği ve onları korumak bir yana rekabet güçlerini azaltıcı bir etki yapacağı söylenmiştir (Öz, 2009: 10).

Korumacılık önlemleri yalnızca iş dünyasının değil hane halklarının alım gücünün azalmasına ve yoksulluk oranlarının da giderek artış göstermesine neden olmuş, bu krizin etkilerinin çok şiddetli olduğu ve alınan korumacılık önlemlerinin de bunu daha da derinleştirdiğinin göstergesidir.

Günümüzde patlak veren her kriz sonrası içgüdüsel bir şekilde gündeme gelen korumacılık söylemi ve bu söyleme karşı tepkilerin de eş zamanlı olarak ortaya çıkmasının sebebinin ardında ise 1929 Büyük Bunalımı deneyimi yatmaktadır.2008 krizi ve 1929 krizi arasında, ABD banka sisteminin zayıflığı, uluslararası mali yapının bozukluğu, ABD’nin dünya ekonomisi üstünde önemli bir söze sahip oluşu, bunalımı önleyecek etkin müdahalelerinin yapılamaması (Durak, 2006: 10) gibi benzerlikler olması sebebiyle krizden çıkış yolu olarak korumacılık önlemleri alınması gerektiği düşünceleri ortaya çıkmıştır.

Küreselleşen dünyada serbest ticaretin en yüksek olduğu dönemlerde patlak veren 2008 krizinden sonra gündeme gelen korumacılık önlemlerine neden karşı durulduğunu anlamak için 1929 Büyük Bunalımdan sonra alınan kararlara yani korumacılık önlemlerine bakılmalıdır. Büyük Bunalım 1929 Ağustos ayından Mart 1933'e kadar sürmüştür. Reel milli gelir ve fiyatları üçte bir oranın da düşmüş, sanayi üretimi yarıdan fazla azalmış, işsizlik oranları \%25'lere ulaşmıştır. Bordo, Goldin ve White (1998)'dan akt: (Öz, 2008: 10). Bu kriz ABD'de o güne kadar görülmüş en büyük kriz olarak tarihe geçmiştir. 1929 krizinin çıkış sebepleri ile ilgili olarak pek çok görüş vardır, ancak genel olarak bakıldığında I.Dünya savaşı sonrası bozulan uluslararası dengelerin savaşın ardından tekrar kurulmasının ve altın standardından çıkmak için gerekli yapısal değişikliklerin yapılmamış olması olarak görülüyor. Yani krizi yalnızca ABD’nin ulusal boyuttaki dengesizliklerine bağlı değildir ayrıca kriz ortamını oluşturan uluslararası ekonomik, politik ve yapısal koşullara da bağlıdır.

1929 Büyük Bunalımının etkileri yaklaşık on yıl kadar sürmüştür, bu krizin etkilerinin bu kadar uzun sürmesinin sebepleri, genişlemeci para ve maliye politikaları uygulamak, bir altın standardına bağlı kalınmış olması gibi nedenlerle dünya ticaretinde daralmalara yol 
aşmıştır. Krizin bu kadar uzun sürmesinde en önemli nedenden biri olarak ABD’nin 1930 da çıkarttı̆̆ 1 Smoot-Hawley ${ }^{4}$ gümrük vergisi yasası gösterilebilir, bu yasa korumacılığın tüm dünyada yayılmasına yol açmış ve krizin etkilerinin on yıl kadar sürmesine neden olmuştur. 1929 krizinin etkilerinin bu kadar uzun sürmesine neden olan korumacılık önlemleri nedeniyle 2008 krizi sonrasında konulacak kota ve tarifelerin 1929 örneğinde olduğu gibi krizin etkilerinin uzun sürmesine sebep olacağı endişesi yatmaktadır.

Krizin etkilerinden çıkış için konulan korumacılık önlemleri arasında en tehlikelisinin olarak finansal korumacılık önlemleri gösterilebilir. Hükümet yardımlarının ardından daha ulusal bir yaklaşım içine giren pek çok banka, özellikle New York, Londra, Frankfurt, Tokyo'daki büyük ve önemli bankalar kendi ülkelerine geri dönmüştür. Özellikle bazı bankalar, hükümetleri tarafından kendi ülkelerinde yatırım yapmaya zorlanmıştır. Benzeri olarak Hollanda da Hollandalı iş adamlarına ve tüketicilerine kredilerini yükseltmeleri karşılığında İng Bank mali destek verilerek kurtarılmıştır (Hufbauer and Stephenson,2009' akt: Durusoy: 2013: 514). Uluslararası bankaların yabancı ülkelerdeki faaliyetlerini durdurmaları, kredi krizine neden olurken, fon bulmakta zorlanan reel sektörlere yönelik kurtarma planlarının da gündeme gelmesine neden olmuştur. $\mathrm{Bu}$ bağlamda finansal korumacılığın yaratacağı sonuçların özellikle $\mathrm{AB}$ için siyasi, ekonomik ve yasal açıdan önemli bir test niteliği taşıyacağı söylenirken, bankacılık sektöründe entegrasyonun sağlanamamış olmasının AB’ye büyük zarar vereceği sorunu ortaya çıkmaktadır.

Korumacılık baskılarının AB ve özellikle Euro bölgesi için ciddi bir tehdit oluşturduğu Avrupa Merkez Bankası tarafından da çok kez ifade edilmiştir. Avrupa Uluslararası Ekonomi Politikaları Merkezi Başkan yardımcısı Razeen Sally; aynı anda hem finansal korumacılık önlemlerinin alınmaya başlanıldığı hem de bankaların kredilerini sınırladıkları bir durumla karşı karşıya olduklarını belirtmiştir. Sally’e göre bazı bankaların finans krizinden yararlanarak finansal korumacılık yapmaktadır. Finansal korumacılığın yarattığı bir diğer tehdit ise, devlet yardımlarının bankacılık dışındaki sektörlere yönelmesidir. İsveç'in otomotiv sektörüne yönelik hazırladığg kurtarma paketi; Fransa'nın otomobil üreticilerine 6 milyar Euro destek sağlaması ve bunun karşılığında istihdam ve üretimlerini dışarı 
taşımamalarını istemesi; İtalya'nın zarar eden havayolu şirketi Alitalia'yı yabancılara kaptırmaması; İspanyol hükümetinin vatandaşlarını İspanyol malı tüketmeye davet etmesi; İngiltere'nin yabancı işçilerin istihdamına tepki göstermeye başlaması korumacılık uygulamalarından bazılarıdır (Euractıv, 2012'dan akt Durusoy, 2013).

Krizin etkilerinden kurtulmak için uygulanan tüm bu korumacılık önlemleri özellikle finansal korumacılık önlemlerin ekonomiler üzerinde yarattığı makro ekonomik bozulmaları en aza indirmek için ulusal paraların değerini piyasalarda oluşan değerden farklılaştırmak için MB kurlara müdahale etmeye başlamıştır. Serbest Piyasa koşullarının geçerli olduğu küresel finans piyasalarında MB'nin kurlara müdahalesi piyasa mekanizmasının aksamasına, haksız kazançların ortaya çıkmasına neden olmuştur. $\mathrm{Bu}$ müdahaleler sonucunda ortaya çıkan duruma kur savaşları denilmektedir.

Küresel finansal krizin ülke ekonomileri üzerinde yarattığı sarsıcı ve yıkıcı etkinin olumsuzluklarını elimine etmek için çözümü dış ticaret olarak gören dünya ekonomileri ticaretteki pazarın paylaşımında pay almanın en kolay yolunun ulusal paranın diğer paralar karşısındaki değer kaybıyla olabileceği düşüncesindedir. Ve bu durumda büyük döviz rezervlerine sahip ülke ekonomileri bu avantajlarını sonuna kadar kullanacaktır (Çin 'in yaptığı gibi). Kur savaşları korumacı önlemlerin, küresel ticaret hacminde yeni daralma dalgalarının öncüsü niteliğindedir. Getiriler hızla azalırken risklerin büyümesi, riskten kaçınma dalgalarının daha uzun süreli olmasını engellemenin zorlaşması bu süreci hızlandırmaktadır (Durusoy, 2013). Korumacılık kur savaşlarını, kur savaşları da dış ticaret dengesizliklerini büyütür ve ticaret savaşlarının en önemli silahı haline gelir.

\section{Kur Savaşları}

Klasik iktisadın yorumunda bir ülkenin zengin olabilmesi için diğer bir ülkenin kaynaklarının, zengin olmaya başlaya ülkeye akması gerektiği kabul edilir. (Akkaş, 2015) Globalleşen dünya da serbest piyasalarda uygulanmaya başlanan para ve kur politikaları ile uluslararası ticarette rekabet farklı boyutlara taşınmıştır, mal piyasaları üzerinde gerçekleştirilen rekabet şekil değiştirerek haksız rekabet piyasası ortaya çıkarmıştır. Ticaret ve para, küreselleşen finansal piyasaların önemini diğer piyasalara göre daha fazla artırmakta ve 
üretilen mal ve hizmetlerin finansal enstrümanlara konu edilebilmesiyle finansal piyasaların etkileri de bir o kadar küresel olmaktadır.

Finansal korumacılığın yol açtığı kur savaşlarının tanımına bakacak olursak şöyle tanımlamak mümkün; Kur savaşları deyimiyle kastedilen şey ülkelerin döviz kuru kullanarak kendilerine ekonomik avantaj sağlamaya çalışmalarıdır. (Eğilmez, 2010) Ulusal paranın değerini düşürmek (devalüasyon), uluslararası ticarette üstünlük kazanmak için uygulanmaktadir.

Kur savaşı kavramı yeni bir kavram değildir. İktisatçı Joan Robinson 1930'lu yıllarda benzer durumu açıklamak, o sırada uygulanan politikaları ' beggar-thy-neighour' (komşuda dilenme politikası) şeklinde bir kavram tanımlamıştır. Eğer bir ekonomi kendi parasını ticaret ortaklarının paralarına göre olması gereken düzeyin altında tutarak onlara daha fazla mal satıyor ve onlardan daha az mal almayı hedefliyorsa o zaman komşudan dilenme politikası kur savaşına dönüyor demektir.

\section{i. Komşudan Dilenme Politikası}

İktisatçı Joan Robinson'nun '’beggar-thy-neighbour'” kavramını, İngiltere'de bir kart oyunundan esinlenerek bulduğu belirtilmektedir. Bir oyuncunun diğer oyuncuyu eleyerek onun aleyhine gelir elde etmesi üzerine kurgulanmış bir oyundur, bu tür oyunlara "sıfır toplamlı oyun", (zero-sum game) denilmektedir. Ekonomik açıdan ' beggar-thy-neighbour', politikası; bir ülkenin ticaret yaptığı ülkelere karşı uyguladığı politika olup kendi ekonomisinde beliren enflasyon, ödemeler dengesi ve işsizlik gibi sorunların çözümüne yönelik olarak ticari ilişkide bulunan ülkeye zarar verici ithalat kısıtlamaları, kur politikaları uygulaması anlamı taşımaktadır. Bu politikanın temel argümanı yerli paranın yabancı para karşısında değerinin düşürülmesi yani devalüasyondur. Yabancı para karşısında değeri düşen yerli para, ihracatın daha ucuz hale gelmesine ve ithalatın pahalı olmasına yol açmaktadır. $\mathrm{Bu}$ durumda ihracat artarken, ithalat azalmaktadır. Bu politikayı uygulayan ülkenin istihdam oranı ve gelirlerinde artış yaşanmaktadır. Sonuç itibariyle politikayı uygulayan ülke açısından sonuçlar olumlu olmakta ancak bu politikaya uygulamaya olanaklı olmayan ülkelerin ciddi zararlara uğramaktadır. Çünkü devalüasyon sonucu parasının değeri artan diğer ülkenin, devalüasyon yapan ülkedeki fiyatların düşmesi sonucunda ithalatı artmaktadır. $\mathrm{Bu}$ durumda 
daha önce kendisinin ürettiği malları, diğer ülkeden daha ucuza almaya başladığı için kendisi üretmekten vazgeçer. (Övgü-Uzunoğlu, 2013).Üretimin azalması ise ülkenin büyümesinin gerilemesi ve buna bağlı olarak istihdamın gerilemesi başlar.

Bu politikanın uygulanmasıyla, ihracat edilen malların üretiminde kullanılan işgücüne ihtiyaç duyulmaz, böyle bir ihtiyaç ortadan kalktığı için işçi çıkarmaları başlar. Başka bir sonuç ise ithalatı artırıp ihracatı azalan ülke dış ticaret açığı vermeye başlar ve ekonomisi dış ticaret hadleri nedeniyle zarar görmeye başlar. İşte kur savaşlarının ortaya çıkış noktası bu politikanın uygulanmasında kaynaklanmaktadır. 'Beggar-thy-neighbour' politikasını tüm ülkelerin aynı anda uygulamaya başlaması kur savaşlarının çıkış nedenidir. Diyebiliriz ki kur savaşı, uluslararası ticari ilişkilerde ülkelerin birbirlerine karşı rekabet avantajı sağlamak amacıyla kendi para birimlerini değerini düşük tutmasıdır. Dünya da kur savaşların ortaya çıkışı 1929 ve 2008 küresel kriz nedeniyle uluslararası ticarette genel bir durgunluk dönemine girildiği dönemlerde ortaya çıkmaktadır. Krizden çıkma politikası olarak görülen devalüasyonlar yani bir ülkenin kendi parasının değerini düşürme politikası ülkeler arası kur savaşlarına yol açmakta ve bir süre yeni krizlerin tetikleyicisi haline gelebilmektedir.

1930’lu yıllardan sonra Dünyada Yeniden Kur Savaşları 2010 Eylül ayında Brezilya Maliye Bakanı Guido Mantega tarafından dile getirilmiştir. Bunun dışında 2013 yılı başında ise, Rusya Merkez Bankası Başkan Yardımcısı Alexei Ulyukayev kur savaşlarına atıfta bulunarak tekrar kur savaşlarını gündeme getirmiştir (Birgün, 2015).

2008 yılında ki gibi şiddetli bir krizin, ekonomik sistem üzerinde derin ve kalıcı sonuçları olmaksızın atlatılması beklenemezdi. Küresel kriz sonrası düşen talep, rekabetçi kur politikaları tartı̧̧masını tekrar ortaya çıkarmıştır. Para birimlerinin değerlenmesini önlemek için başlayan tartışmalar önce kur savaşları biçimini almış, tartışmalar kur rejimlerini de içine alacak şekilde genişlemiştir. Kur Savaşları'nın çıkmasına neden olan etmenler şu şekilde siralanabilir:

- Durgunluk hemen hemen bütün dünyada devam etmektedir.

- İsssizlik artmaya devam etmekte, bir türlü düşüş sürecine girememektedir.

- Mali ve parasal genişleme yeterli olmamaktadır. 
- İç pazarın durduğu bir ortamda her ülke diğerinin pazarına girmenin yolunu aramaktadır.

- Ülkeler dolar fazlalığının kendi paralarını güçlendirdiğini fark ettiği için merkez bankaları yabancı parayı (büyük ölçüde dolar) toplamaktadır. (Uzunoğlu, 2013:6)bu da diğer para birimlerinin arzının da artması anlamına gelmektedir.

1944'te oluşturulan Bretton Woods sistemi, rekabetçi devalüasyonları önlemeyi hedeflemiş ve ana kural olarak sabit, değişmeyen döviz kurları kabul edilmiş, dolar da altına bağlanarak dünya parası olmuştur. Devalüasyon, ancak IMF'nin oyuyla istisnaen yapılabilirken, Breton Woods sisteminin ana kurallar1, metropol ekonomiler arasındaki dengesizliklerin baskısıyla 1971-1973 yıllarında değiştirilmiş, doların değeri düşürülmüş; altınla bağlantısına son verilip ve büyük paralara arasında dalgalı kurlara geçilmiştir. Sistemin patronları arasındaki ilk 'kur savaşları' böyle başlamıştır. 1985'te ABD “'paralarınızı ucuz tutuyorsunuz"' suçlamasıyla Almanya ve Japonya'ya karşı bir ' "kur savaşı" daha açarak ve Plaza anlaşması ile Yen ve Mark’ın değerlendirmesini sağlamıştır (Boratav, Birgün, 2010).

Kur Savaşlarının tekrar başlama tarihi olarak Aralık 2012'de Shinzo Abe'nin Japonya Başbakanı olarak seçilmesi ve ekonomi politikasını değiştireceğini söylemesi gösterilebilir. Başbakan Abe, Japon Merkez Bankası'nın enflasyon hedefini \%2'ye çıkarmasını ve bu hedefe ulaşıncaya kadar devlet tahvili satın almasını istemiştir. Japon MB'nin\%2'lik enflasyonu gerçekleştirdiğinde, Japonya faiz oranları reel anlamda negatif seviyeye düşecektir. Nitekim deflasyon nedeniyle, son 10 yılın büyük bir bölümünde reel faiz oranları ekonomideki durgunluğa rağmen pozitif seviyede olması Japon para birimi Yen'i daha güçlü kılmış, öte yandan ihracatçılar için sıkıntı oluşturmuştur. Başbakan Abe'nin bu önerisi kur piyasasında ciddi sonuçlar açmış ve Yen'in Dolar karşısında değer kaybetmesine neden olmuştur. Para genişlemesi yanlısı olan Abe'nin Başbakan olmasından sonra değer kaybetmeye başlayan Japon Yeni Amerikan Doları karşısında 90.25 ile son iki buçuk yılın en düşük seviyesine gerilemiştir. Japonya'nın bu tutumuna karşılık en açık tepki Fransa'dan gelmiştir. Fransa'nın tepkisi Avrupa'nın kur savaşlarına girip girmeyeceği tartışmalarını da başlatmıştır. (Uzunoğlu, 2013:6) 
2001 yılında Çin'in yerel para birimi Yuan'1 ABD Dolarına sabitlemesiyle kur savaşı daha da belirginleşmiştir.

\section{ii. $\quad$ ABD ve Çin'in Kur Savaşları Örneği}

Kur savaşlarının tekrar gündeme gelmesiyle birlikte ilk olarak ihracatta lider konumda olmasından dolayı gözler Çin'e çevrilmiştir.

Küresel kriz öncesi dönemde, Yuan, ABD Doları'na endekslemiş ve haksız rekabet başlatmıştır. Bu durum Dolar'daki değer kaybına bağlı olarak, Çin ekonomisin avantajını artırmış, Çin mallarının uluslararası mal piyasasında daha fazla öne çıkamasın sebep olmuştur. Çin malları uluslararası mal piyasasında avantajı hale gelmesi üzerine ABD, Çin'e yerel parasının değerinin düzeltmesine ilişkin baskılarını artırmıştır. Oysa Çin'i, kendi çıkarları için düşük tuttuğu yerel parası sebebiyle, ABD ekonomisinde önemli tahribatlar yaratmakla suçlayan FED, mortgage krizi sonrasında aynı oranı GOÜ (Gelişmekte Olan Ülke) ekonomilerine kendisi uygulamıştır.

Küresel Krizinin gerçekleşmesinin ardından ülkelerarası dış açık ve dengesizliklerinin azaltılması gerektiği için, ABD ve Çin arasında da kur savaşları mücadelesi başlamıştır. Krizden uzun bir süre çıkmanın mümkün olmadığının anlaşılması üzerine, ABD Çin'e para biriminde düzeltmeler yapması gerektiğini yaptığı ithalatı azaltmak amacıyla Çin'in para birimini değerlendirmesini talep etmiştir. Ancak Çin sahip olduğu avantajı kaybetmemek için tutumunu devam ettirmiştir, 2011 yılı sonuna doğru parasının Dolar'a endeksliligini kaldırıp, piyasa koşullarına bırakmıştır. Bu dönemde Çin sahip olduğu 2,5 Trilyon Dolar’ı aşan döviz rezervini, kurlara müdahale etmek ve ticarette pazar payını arttırmak için kullanmaya devam etmiştir. ABD açısından durum ele alındığında; ABD Merkez Bankası'nın (FED) ABD ekonomisini canlandırmak ve deflâsyonu engellemek amacıyla başlattığı QE olarak bilinen Miktarsal Genişleme ${ }^{5}$ (Quantitative Easing-QE) süreçleri önem taşımaktadır. ABD’nin 2010 yılının Ekim ayı başında 600 Milyar Dolarlık kamu kâğıdını geri alacağını duyurması küresel gündemin birinci sırasına oturmuştur. 2011 yılı itibariyle parasal genişlemenin miktarı 2,3

\footnotetext{
${ }^{5}$ Miktarsal genişleme modeli, faiz oranlarını düşürerek piyasada dönen paranın artırılamadığı durumlarda kullanılır. Merkez bankalarının bunu yapma şekli varlıkları satın alarak piyasaya para sürme şeklidir.
} 
trilyon doları bulmuştur. FED' in ikinci genişleme (QE-2) politikasını uygulaması ile doların değer kaybetmeye başlamıştır ve bunu üçüncüsü izlemiştir. Bu süreç ile dolarda görülen miktarsal artış, Euro karşısında değer kaybı yaşanmasına yol açmıştır.

Kurlara yönelik Avrupa Merkez Bankası'nın bir girişimde bulunmasının çok zor olduğu görüşü, kur savaşlarına karşı en korunmasız bölgenin Euro Bölgesi olmasına neden olmaktadır. Avrupa'da daha önce parasal genişlemeyi 'borç krizi" sorununu çözmeye ve zordaki bankalara likidite vermeye yönelik olarak kullanılmıştır. Bu dönemde, Amerikan para politikasının yönlendirdiği Dolar/Euro paritesi Avrupa'daki parasal genişlemeyle bir ölçüde dengelenmiştir. Aksine Avrupa'da bankaların likidite sorununu çözmeye yönelik yapılan parasal genişlemeden geri dönüş söz konusudur. Avrupa bankaları Avrupa Merkez Bankası'ndan 3 yıl vadeli yıllık yüzde 1 faizle aldıkları borçları erken geri ödeme eğiliminde bulunmaktadır. Kur savaşlarından bağımsız olarak bu durum Euro'nun değer kazanmasına neden olmuştur. Ortaya çıkan bu durum nedeniyle Avrupa önemli bir çelişkiyi yaşamaktadır. Avrupa ekonomilerinin kalıcı bir düzelme yoluna girebilmesi için, ekonomik büyümenin tetiklenmesi ve büyümenin itici güçlerinden biri Euro'nun diğer paralar karşısında değer yitirmesi gerekmektedir. Ancak diğer ülkeler kendi paralarının değerini düşürmeye çalıştıkça, Euro değer yitirmemekte, aksine değer kazanmaktadır. Bu durumda AB'nin kur savaşlarına girip girmeyeceği yönünde tartışmaları arttırmaktadır (Övgü-Uzunoğlu, 2013: 7).

Çin'in kurlarda yaptığı müdahaleler dolayısıyla uluslararası ticarette elde ettiği haksız kazanç ABD'de dışındaki diğer ülkelerden de seslerin yükselmesine neden olmuştur. $\mathrm{Bu}$ tepkilerin sebebi ise Çin'in başlattığı kur savaşlarının uluslararası ticarete 'ticaret savaşları' olarak yansımaya başlamasıdır.

Çin'in kurlardaki düşüşlerin ticarete nasıl yansıma bulduğuna örnek olarak; Dünyanın en büyük güneş paneli üreticisi olan Çin 2011'de AB'ye yaptı̆̆ı panel ihracı 21 milyar avroyu bulmuş. Bu Çin'in bölge üreticileri aleyhine damping uyguladığı iddialarınızda gündeme getirmiştir. Bunun üzerine AB Ticaret Komisyonu Başkanı Karel De Gucht, Çin’in Avrupa'da sattığı panellerin fiyatının yüzde 88daha yüksek olması gerektiğini açıklamıştır. Çin uyguladığı bu damping ile ihracatçı ülke, mallarını değerinin altında satarak piyasa da 
rakiplerine karşı üstünlük sağlamıştır. Bu nedenle Avrupa komisyonu Çin'den ithal edilen güneş panellerine damping karşı1tı vergi getirmiştir (Birgün, 2013).

Çin'inin dünya ihracatındaki erinin önemli olması nedeniyle parsını devalüe etmesi diğer ülkelerin her gün başka bir pazardan çekilmesine sebep olmuştur. Bu politikaların durdurulması yönünde birçok adım atılmaya başlanmıştır. Bunlardan en önemlisi ABD Temsilciler Meclisi'nde 2010 yılında 79'a karşı 348 gibi ezici bir çoğunlukla kabul edilen, ‘, Kur Reformu Yoluyla Adil Ticaret Geliştirme'” adlı yasadır. Kabul edilen yasa, Çin'in kur politikasının Adil olmayan sübvansiyon tespiti sağladığı halinde ABD Ticaret Bakanlığı'na Çin'in diğer ülkelerden ithal edilen mallara vergi getirmeyi değerlendirme imkânı vermektedir. Çin tarafından bu yasaya tepkiler gelmiştir, Dünya Ticaret Örgütü'nün kurallarına aykırı olduğu nu söyleyerek itiraz etmiştir. Çin’e bu şekilde baskı uygulamasının sebebi, aslında hem Çin'in ihracatta lider olmasına rağmen haksız rekabet etmesi, hem de bu durumun diğer ülkeleri etkileyeceği düşünülerek adeta domino etkisi meydana getireceği adımdır ki, bu korkuların merkezi ABD’dir. (Akkaş, 2015)

Çin 2010 yılından bu yana parasının değerini düşürme politikalarına bir yenisini de eklemiş ve 2015 Ağustos ayında para birimi Yuan'1 bir hafta içinde iki kez devalüe etmiştir ve böylece Çin'in resmi para birimi 2011 Ağustos ayından bu yana en düşük seviyesine gerilemiş oldu. Çin'in bu davranışı uluslararası piyasalarda bir kez daha kur savaşı endişesine neden olmuştur.

Yuan devalüasyondan Çin piyasalarında yüzde 3,5 değer kaybetmiş ve uluslararası piyasalarda yüzde 4,8 gerileyerek son dört yılın en düşük seviyelerine düşmüş. Müdahaleden sonra dolar/yuan paritesi 6.32'den 6.44'e kadar yükselmiştir. Euro/yuan paritesi de 6.98'den 7,14 seviyelerine kadar çıkmıştır. Çin'in üst üste kura yaptığı beklenmedik müdahale uzun süreli bir düşüş dönemine girildiği algısının güçlenmesine ve piyasalarda panik havası oluşmasına neden olmuştur.

Çin'in parasını devalüe etmesi Asya ülkelerinin para birimlerinde de kayıplar olmasına yol açtı. Endonezya Rupisi ile Malezya Ringgit’i 17 yılın en düşüğünü, Avustralya ile Yeni Zelanda Doları 6 yılın en düşük seviyesini test etti. Asya para birimlerinin dolara karşı değerini gösteren Asya dolar endeksi ise yüzde 0,7'lik kayıpla 6 yılın en düşük seviyesine 
indiği gözlemlenmiştir. Çin'in parasını devalüe etmesi Fed'in doların yuan karşısında değerlenmesini göze alamayacağı için faiz artırımını geciktireceği yorumlarına neden olmuştur. Ancak 2008 yılından beri düşük faiz politikası izleyen Fed16 Aralık’ta faizi 0,25 oranında artırmıştır (Sözcü: 2015).

Kurlar da yapılan bu oynamalar ülkelere arası haksız kazanca yol açması nedeniyle tepkiler almaktadır bu nedenle Antalya'da yapılan G20 zirvesinin önemli başlıklarından biri olmuştur.

2015 y1lı kasım ayında Antalya'da gerçekleştirilen G20 Liderler Zirvesi öncesi hazırlık süreci kapsamında gerçekleşen G20 Maliye Bakanları ve Merkez Bankası Başkanları toplantısı sonuç deklarasyonunda Çin'in para birimi Yuan'1 rekor seviyede devalüe etmesine karş1 " Rekabetçi devalüasyonlardan uzak duracağız. Korumacılığın her türlüsüne karş1 mücadele edeceğiz" denildi. Ekonomik temelleri ve göstergeleri yansıtmayan, ekonomik yapıya uyumsuz döviz kurlarından kaçınmak için esnek döviz kur sistemlerinin önemine vurgu yapılarak korumacılığın her türlüsüne karşı olunduğu belirtildi (Birgün, 2013).Antalya da gerçekleştirilen G20 Liderler Zirvesi'nde hazırlık aşamasında belirtikleri kararlara uyacaklarını ve her türlü korumacılığa karşı duracaklarını bildirdiler.

\section{iii. Türkiye Kur Savaşları’nın Neresinde}

Türkiye 2001 krizi sonrası bankacılık sektöründe ciddi yapısal reformlar yaptığı için küresel krizi 'görece' rahat atlatmayı başarmıştır. Ancak Türkiye kriz öncesi olduğu gibi kriz sonrası da ticaret açığı vermeye devam etmiştir. Küresel kriz sonrası dünyada korumac1 önlemeler gündemdeyken Türkiye; bir yandan "rekabetçi kur politikası izleyerek canlılık yaratma”, diğer yandan da süregelen küresel dengesizliklerin yaratmakta olduğu bol ve ucuz kredi olanakları, gelişmekte olan piyasa ekonomilerine akmakta olan spekülatif sermaye akımlarının ana kaynağını oluşturmakta ve bu ülkelerin ekonomilerini ucuz kur (aşırı değerli ulusal para) sarmalına bağımlı tutmaktadır. Kur Savaşlarının Türkiye’ye Yansımaları, uluslararası düzeyde yaşanan likidite hacminin genişlemesi ve yaratmakta olduğu kur baskıları aralarında Türkiye'nin de bulunduğu yükselen piyasa ekonomilerinde dengesizliklerin ana kaynağını oluşturmaktadır. (Yeldan, 2010) 
Kriz sonrasında dış ticaret hadlerinin Türkiye aleyhine seyretmeye devam etmiş ve ihracat gelirlerini olumsuz etkilemiştir. Bu olumsuzluğun yanı sıra bir de TL'de değerlenme meydana geliyor. Türkiye hızlı ve sağlıklı bir büyüme sürdürebilmek için ihracat gelirlerini artırmak ve cari açığını azaltmak zorunda. Küresel koşullar, ihracatın ithalata bağımlı yapısı ve enflasyonun uluslararası standartlara göre yüksek seviyesi, kura müdahale etmeyi bir politika seçeneği olarak zayıflatıyor.

TL'nin reel olarak değer kazanması, reel faiz oranının negatife düştüğü bir ortamda ülke içine sermaye girişlerinin devam etmesine ve böylece büyümenin finanse edilebilmesine imkân veriyor. Türk lirasındaki hızlı reel değerlenmenin ithalatı ucuzlattığı ve zaten gerileyen ihracat fiyatları ve düşük dış talep koşullarında ihracatçının gelirlerini sınırladığı da bir gerçek. Ama TL'nin değer kazanmasını engellemek üzere yapılabilecek müdahaleler, hem ithal girdiler nedeniyle ihracatçının üretim maliyetini artırma, hem de enflasyonla mücadeleyi zorlaştırma ve büyümeyi yavaşlatma riski taşıyor. Türkiye hızlı ve sağlıklı bir büyüme sürdürebilmek için ihracat gelirlerini artırmak ve cari açığını azaltmak zorunda. Küresel koşullar, ihracatın ithalata bağımlı yapısı ve enflasyonun uluslararası standartlara göre yüksek seviyesi, kura müdahale etmeyi bir politika seçeneği olarak zayıflatıyor.

Fatih Üniversitesi Ekonomi Bölümü Öğretim Üyesi Prof. Dr. Vildan Serin Türkiye'nin Cari işlemler açığı veren bir ülke olduğunu ihracatın artırılması sadece düşük değerli Türk Lirası ile mümkün olmadığını, verimliliği ve kaliteyi artırıcı önlemlerin başında da yenilikler gelmektedir. $\mathrm{Bu}$ da ihracatın dışa bağımlılık oranının azaltılmasıyla ilgilidir. Türkiye bu savaşın içinde değil, sadece izleyicidir "Çünkü Türkiye'nin dünya ticaret hacmindeki payı düşüktür. İkincisi neden ise Türkiye bütçe ve cari açığı nedeni ile sermaye girişlerini sürdürmek için aşırı değerli kur politikası uygulamak zorunda kalmaktadır. Açıklaması Türkiye’nin kur savaşlarının neresinde olduğu konusunda açıklık getirmektedir.

\section{Kur Savaşları Ticaret Savaşlarına Döner mi?}

Küresel ekonomik krizin özellikle gelişmiş ülkelerde ihracat pazarının daralmasına ve dünyada ticaret ve dolayısıyla güç ekseninin batıdan doğuya doğru kaymasına yol açmıştır. Gelişmiş ülkelerin güçlerini devam ettirebilmek için ihracatlarını artırmaya ihtiyaç duymaya 
başlamıştır. ABD ve Avrupa Birliği küresel nüfusunun onda biri ile dünyadaki GSYİH'nin yarısını, uluslararası ticaretin üçte birini gerçekleştirmektedir (Özdemir, 2013).

Çin'in küresel kriz sonrası uyguladığı parasını devalüe politikası sonrası tekrar gündeme gelen kur savaşları dünya ticaretinde büyük hacme sahip olan $A B D, A B$ gibi ülkelerde endişe yaratmaya başlamıştır. Sanayinin üretim devleri Amerika ve Avrupa, giderek zayıflayan ekonomileri, Çin sanayi ürünlerinin dünya piyasalarındaki hızlı artışı, dünya ekonomilerinin merkezinin Asya'ya kayması gibi etkenler nedeniyle Amerika ve Avrupa rekabetle değil ancak işbirliği ile egemenliklerini koruyacaklarını anlamışlar ve Transatlantik Ticaret ve Yatırım Ortaklığı (TTIP) Anlaşması imzalamaya karar vermişlerdir (TÜSİAD).

"Transatlantik Ticaret ve Yatırım Ortaklığı" iki ekonomik gücü serbest ticaret anlaşması ile bir ticaret bloğu haline getirmeyi planlayan bir girişimdir. Bilgi olarak, serbest ticaret anlaşmaları tarafların karşılıklı olarak tarifeleri, ithalat kotalarını ve ticaret kısıtlamalarını kaldırdığı anlaşmalardır. AB ve ABD serbest ticaret anlaşması da öz olarak bunu amaçlamaktadır fakat bu iki ekonomik güç arasında tarım dışı gümrük tarifeleri göreceli olarak oldukça düşüktür (\%3 civarında). (Küresel Sorunlar Platformu). ABD, Japonya'dan Avustralya'ya kadar uzanan Transatlantik Ticaret ve Yatırım Ortaklığı anlaşmalarının ardından daha sonra Euro bölgesi ile ilgili Serbest Ticaret Bölgesi önermiş ve Irak serbest ticaret anlaşmaları imzalamıştır. Tüm bu yapılan anlaşmaları Çin'in parasını devalüe etmesi ve dünya ihracında önemli olması nedeniyle lider ekonomi konumuna gelmesi korkusu yatmaktadır. Oluşabilecek yeni ticaret düzeni içerisine kendilerine yer bulma çabasında olduğunu söyleyebiliriz. Asıl soru olan kur savaşları ticaret savaşlarına döner mi sorusun gelirsek, kur savaşları ile ticaret savaşlarının birbirinden farklı şeyler olduğunu söylemek mümkün değildir. Ülkeler arası yapılan kur savaşlarının amacı zaten dış ticarette mümkün olan en yüksek kazancı sağlamaktır.

Dünya ticaret savaşları sadece Çin'in ekonomisindeki dengesizlikleri gidermek için yaptığı gibi parasını devalüe etmesi ya da anti-damping vergi uygulaması gibi bir nedenden ortaya çıkamamaktadır. Ticaret savaşları siyasi ve askeri anlaşmazlıklar sonucunda da ortaya çıkabilir. Bunu en yakın örneğini Türkiye'nin Rus uçağını sınır ettiği gerekçesiyle düşürmesi olarak gösterebiliriz. Rusya'nın Türkiye'nin bu askeri hamlesi sonucu silahlı fiziki bir 
saldırıdan çok ticari yaptırımların olduğu bir savaş açacağı daha muhtemel gözüküyor. Rusya'nın Türkiye'den beyaz et alımını durdurması, Türkiye'den ithal ettiği limonları geri çevirmesi, tekstil sektörü ve inşaat sektörü gibi sektörler de var olan Rusya ve Türkiye anlaşmaları düşünüldüğünde, Rusya krizi olarak adlandırılan bu durumun Türkiye ekonomisinde sorunlar açacağını hatta Rusya Türkiye arasında yeni bir ticaret savaşına neden olabileceğini söylemek mümkün.

\section{SONUÇ}

1923 Büyük Bunalımdan sonra dünya ekonomisini derinden etkileyen 2008 Mortgage Krizi 'de denilen Küresel Krizin patlak vermesi ve Büyük Bunalımı yaşamış ülkelerin geçmiş deneyimlerine dayanarak, bu kriz sonrası çeşitli önlemler alıp krizin getireceği sorunlara çözüm getirmek istemişlerdir. Bu çözümler arasında ilk akla yöntem ise korumacılık politikaları olmuştur. Dünya genelinde serbest ticaret politikalarının geçerli olduğu bir dönemde patlak veren bu kriz sonrasında gündeme gelen korumacılık politikalarının serbestleşmenin önünde bir engel olması, uluslararası ticarette haksız kazançlara neden olması gibi sonuçları olması nedeniyle korumacılık politikalarına karşı ciddi karşı çıkışlar olmuştur. Finansal korumacılık ise korumacılığın en tehlikelisi durumdadır, uygulanan finansal korumacılık nedeniyle kurlarla oynanması ve ülke parasını değersizleştirme politikası Çin'in örneğinde olduğu gibi ciddi haksız kazançlara yol açmaktadır. Uygulamaya konana korumacılık politikaları gelişmiş ve azgelişmiş ülkeler arasında kayda değer farklılıklar yaratmakta ve krizin etkilerini derinleştirmektedir.

Krizden çıkma bahanesiyle uygulanan korumacı politikalar ve kurda oynamalarının tümü aslında dış ticarette kazanç sağlamak amacıyla yapılmaktadır. Dış ticaretten kazanç sağlamak amacıyla yapılan bu politikalar, ülkeler arasında ticaret savaşlarına dönüşmekte. Zaten yeterince gelişmemiş olan ekonomileri nedeniyle az gelişmiş ülkeler ticaret savaşlarına katılıma olanağı bulamamakta ve en ağır şekilde etkilenenler olmaktadır. Bugün geldiğimiz aşamada yani küreselleşmiş sermaye akımları sistemi altında meydan gelebilecek kur savaşları ya da ticaret savaşları nasıl çözümlenebileceğine ilişkin bir alt yapı henüz bulunmuyor. Ve bu durum ülkeler arası ekonomik farklılıkların derinleşmesine, güçlü ekonomilerin gücünün daha da ivme kazanmasına sebep olurken diğer yandan güçlü olmayan, 
üretimi ve gelişimi yabancı kaynaklara bağlı olan ülkelerin daha derin krizlere sebep olmasına sebep olmaktadir.

\section{Kaynakça}

Akkaş E. (2015), “Kur Savaşları nedir? Çin’in Kur Savaşlarında Oynadığı Rol,” İktisat ve Biz Dergisi

Ateş, D. (2010), “Küresel Ekonomik Kriz Devlet ve Dış Politika”, Uluslararası İnsan Bilimleri Dergisi, 7(1), 912-937.

Başaran C. (2015), “Ticaret savaşları”, http://www.bloomberght.com/htyazarlar/cuneyt-basaran-2071/1831803-ticaret-savaslari/Accessed 24.10.15

Başaran C. (2013), "Kur Savaşlarını Bırak Ticaret Savaşlarına Bak" http://www.bloomberght.com/yorum/cuneyt-basaran/1315633-kur-savaslarini-birak-ticaretsavaslarina-bak-bolum-ii/Accessed 27.02.13

Boratav K. (2010), “Kur Savaşlarının Evveliyatı”, Birgün Gazetesi

Bussière, Matthieu, Emilia Pérez-Barreiro, Roland Straub ve Daria Taglioni (2010), "Protectionsist Responses to the Crises Global Trends and Implications", The European Central Bank (ECB, Occasional Paper Series, No. 110/May.

Durusoy S. (2014), "Kur Savaşı Endişesi Yeniden Artıyor”, Dünya Gazetesi,11.05.2014

Durusoy S. (2013), "Krizin Orta ve Uzun Vadeli Yıkıcı Etkisi: Yükselen Korumacilı", Internatıonal Conference On Eurasian Economies,

Eğilmez, M. (2013), “Kur Savaşları nedir?” mailto:mahfi.eğilmez@gmail.com 25.02.2013

Evenett, Simon J. (2010), "The State of Protectionism on the Eve of the Seoul G20 Summit”, Nov., http://www.voxeu.org/index.php?q=node/5753 
İzmen, İ. (2010), “Kur Savaşlarının Ortasında Ekonomi Politiği”, TÜSİAD Görüş Dergisi, 65

İzmen, Ü. (2010), "Kur Savaşları Korumacı Ticaret Savaşlarına Yol Açar mı?” TÜSİAD Görüş Dergisi, 65

Kalaycı, İ. (2008), "Küresel Finansal Krizi Sonrasında Dış Ticarette Korumacıllk: Paradigma Kayması (mı?)", Sayıştay Dergisi, 161

Komşu Dilenci Politikası (2013), Milliyet,

Övgü, P. Uzunoğlu, H. (2013), "Dünyada Kur Savaşları Alarmı”, AR\&GE Bülten, İzmir Ticaret Odas1, http://www.izto.org.tr/portals/0/argebulten/ovgu_hande_kursavaslari.pdf

Öz, S. (2009), Büyük Bunalım Deneyimi Işı̆̆ında Küresel Kriz, Ekonomik Araştırma Formu TÜSİAD

Öz, S. (2009). “Kriz ve Korumacılık: Tarih Tekerrür Edecek mi?”, http://www.ku.edu.tr/ku/images/EAF/erf_wp_0904.pdf

Sözcü Gazetesi (2015), "Çin tetiği çekti, yeni kur savaşları başlıyor." http://www.sozcu.com.tr/2015/ekonomi/cin-tetigi-cekti-yeni-kur-savaslari-basliyor908140/Accesed13.08.15

Ticaret Savaşları Nereye (2013), http://www.bloomberght.com/haberler/haber/1316803-ticaret-savaslari-nereyegidiyorv/Accesed 08.03.13

Tunç, H. (2013), “Kur Savaşları ve Pazar Paylaşımı”, http://www2.istanbul.edu.tr/?p=18626리.01.2013

Üçer, M. (2010), “Kur savaşlarını Fırsata Çevirmek” TÜSİAD Görüş Dergisi, 65

Yeldan, E. (2010), "Kur Savaşları ve Döviz Kurunda Denge Sorunu”. TÜSİAD Görüş Dergisi, 65 
FSECON ERTÜRK, N.. (2017), “Ticaret Savaşlarl ve Dünya Ekonomisine Etkileri”, Fiscaoeconomia, Vol.1(2), 88-112.

Yeşilada, A. (2010), “Komşudan Çal”, TÜSİAD Görüş Dergisi, 65

Y1lmaz, K. (2009), “Küresel Kriz, Durgunluk ve Artan Korumacilık Eğilimi”, Ekonomik Araştırma Formu, TÜSİAD 